http://jurnal.unipasby.ac.id/index.php/jsbr

\title{
PENGARUH KINERJA FINANSIAL UMKM TERHADAP PENGEMBANGAN EKONOMI LOKAL DI KABUPATEN SIDOARJO
}

\author{
Julinda Prastika Pratama ${ }^{1}$, Teguh Purwantoㄹ, Aji Prasetyo ${ }^{3}$ \\ Universitas PGRI AdiBuana Surabaya \\ julindaprastikapratama@gmail.com ${ }^{1}$, teguhpwt@gmail.com², ajiprasetyo@unipasby.ac.id ${ }^{3}$
}

\begin{abstract}
The business in Indonesia cannot be separated from the role of Micro, Small and Medium Enterprises (MSMEs) in the economy of a region. This study describes the assessment in a business unit's financial performance using NPM and ROE analysis methods The total population in this study was 448 business units that have been registered at the Department of Cooperatives and SMEs in Sidoarjo Regency and obtained a sample of 82 business units with a sampling technique that is simple random sampling. The results of hypothesis testing show that the assessment and picture of financial performance influences the development of the local economy in Sidoarjo Regency.
\end{abstract}

Keywords: MSME Financial Performance, Local Economic Development.

\section{PENDAHULUAN}

Di Negara-negara berkembang seperti Indonesia UMKM berperan penting bagi perekonomian seperti perluasan lapangan kerja, peningkatan pendapatan yang merata, percepatan pertumbuhan ekonomi daerah, serta berkontribusi bagi peningkatan pendapatan daerah. Dengan kesempatan kerja serta bentuk meningkatnya pendapatan di masyarakat, ini merupakan pemberdayaan UMKM dalam hal penanggulangan kemiskinan. Kemampuan UMKM dapat dilihat melalui kinerja keuangannya. Menurut Della (2015) untuk menilai bagaimana kinerja keuangan suatu usaha dilakukan dengan metode analisis rasio keuangan.

Berkembangnya UMKM yang ada di dalam suatu daerah menjadi bagian yang saling berkaitan atau berkesinambungan dengan program pengembangan usaha yang ada. Dengan adanya perkembangan UMKM, ini menjadi pergerakan terpenting di dalam perekonomian suatu daerah seperti di Kabupaten Sidoarjo. Pemerintah daerah Kabupaten Sidoarjo membuat serta melaksanakan program-program yang di dalamnya bertujuan untuk mendobrak laju perkembangan UMKM. Beberapa programnya adalah memberdayakan usaha, memberi pembiayaan usaha, begitu halnya dengan berbagai informasi mengenai suatu usaha, serta berbagai program seperti mitra usaha yang sudah diatur dan sesuai dengan perundang-undangan.

Mengingat pentingnya peran UMKM maka penulis melakukan penelitian yang berjudul "Pengaruh Kinerja Finansial Usaha Mikro Kecil dan Menengah (UMKM) Terhadap Pengembangan Ekonomi Lokal di Kabupaten Sidoarjo".

\section{TINJAUAN PUSTAKA}

\section{Usaha Mikro Kecil dan Menengah (UMKM)}

UMKM merupakan unit usaha ekonomi yang dimiliki oleh seseorang atau kelompok yang mana kegiatan usahanya dilakukan oleh masyarakat lokal itu sendiri. Pengelolaan usaha ini dilakukan secara sederhana, sehingga banyak menjadi pilihan masyarakat Karenamemerlukan modal yang relatif kecil dan memiliki fleksibilitas dalam aktivitasnya (Tanjung, 2017).

Arini (2018) menjelaskan UMKM merupakan suatu kegiatan ekonomi yang mana masyarakatnya mempunyai modal terbatas. Kini, UMKM sudah dapat dikatakan sebagai tempat penyedia tenaga kerja. UMKM juga dijadikan sebagai rekanan usaha seperti contohnya dalam penyediaan bahan baku, suku cadang, atau dalam bentuk jasa yang lainnya. Sifat dari UMKM ini adalah lincah yang pada umumnya dapat bertahan di kondisi ekonomi yang tidak stabil.

\section{Pengukuran Kinerja UMKM}

Pengumpulan, penganalisis, pelaporan suatu informasi yang ada keterkaitannya dengan tingkat kinerja dari karyawan ataupun bisnis secara menyeluruh merupakan cara untuk mengukur kinerja usaha (Arini, 2018). Indikator kinerja meliputi:

a. Indikator yang mengukur kinerja hasil (resultindicator) meliputi pendapatan, laba bersih, pangsa pasar, dan kepuasan pelanggan. 


\section{Journal of Sustainability Business Research (JSBR)}

\section{Vol-1,Issue-1,Desember (JSBR)}

\section{E-ISSN: 2746-8607}

http://jurnal.unipasby.ac.id/index.php/jsbr

b. Indikator yang mengukur kinerja proses (performanceindicator) meliputi ketepatan waktu pengiriman barang, persentase keluhan pelanggan yang diselesaikan, dan jumlah sales calls yang dilaksanakan dalam periode tertentu.

\section{Indikator Kinerja Perspektif Finansial}

Indikator Kinerja Perspektif Finansial adalah parameter-parameter keuangan yang menjadi ukuran kinerja keuangan perusahaan. Kinerja aspek finansial yang dipilih umumnya mencerminkan laba dan kekayaan yang dimiliki perusahaan yang dapat dilakukan pengukuran dengan pendekatan rasio profitabilitas (Arini, 2018). Berikut ini pengukuran dalam rasio kinerja prespektif keuangan UMKM:

\section{a. $\quad$ Net Profit Margin (NPM)}

NPM merupakan rasio pengukuran laba bersih atas pendapatan unit usaha mikro kecil dan menengah. diperoleh Net Profit Margin (NPM) dengan dinyatakan persentase.

$$
\text { NPM }=\frac{\text { Earning After Tax }}{\text { Equity }}
$$

\section{b. Return on Equity (ROE)}

ROE digunakan dalam penunjukan suatu tingkat efektivitas tim manajemen usaha yaitu bagaimana memperoleh laba yang dihasilkan dari investasi para pemegang saham dan dinyatakan juga dalam persentase.

ROE = Earning After Tax

Equity

\section{Pengembangan Ekonomi Lokal}

Proses dimana masyarakat setempat yang berasal dari keseluruhan sektor usaha ikut berpartisipasi ataupun menjalin kerjasama yang fungsinya adalah untuk mempengaruhi berbagai kegiatan ekonomi lokal supaya bisa mencapai ekonomi yang berkesinambungan merupakan arti dari suatu pengembangan ekonomi lokal. Tujuan lainnya yaitu supaya bisa membuka lapangan pekerjaan serta perbaikan ekonomi masyarakat, termasuk penduduk miskin dan yang termarginalkan. Pengembangan ekonomi lokal mendorong sektor publik, swasta, akademisi, dan masyarakat sipil untuk membangun kemitraan dan kerjasama untuk menemukan solusi lokal bagi tantangan ekonomi bersama. Proses pengembangan ekonomi lokal berupaya memberdayakan para pemangku kepentingan untuk mampu menggunakan secara efektif tenaga kerja, modal, dan sumber daya lokal lainnya untuk mencapai prioritasprioritas lokal (penyediaan pekerjaan, mengurangi kemiskinan, stabilitas ekonomi lokal, dan mendorong pajak lokal untuk memberikan pelayanan terbaik (Nugroho, 2018).

Adji (2011) mengartikan pengembangan ekonomi lokal sebagai suatu usaha yang dapat mengoptimalkan manfaat sumber daya lokal dimana ada keterlibatan sekelompok orang dengan usahanya, serta pemerintah di dalam pengembangan ekonomi daerah.

\section{Kerangka Konseptual}

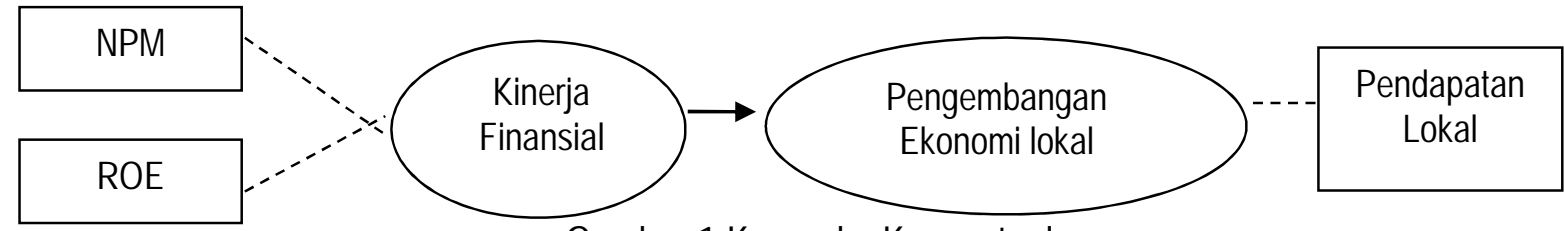

Gambar 1.Kerangka Konseptual

Penelitian ini merupakan penggambaran serta pengukuran kinerja finansial UMKM terhadap pengembangan ekonomi lokal di Kabupaten Sidoarjo yang diukur melalui pendekatan perspektif keuangan UMKM yaitu NPM dan ROE. Sedangkan pengembangan ekonomi lokal diukur menggunakan indikator Pendapatan Asli Daerah (PAD). Untuk melihat pengaruh kinerja finansial UMKM terhadap pengembangan ekonomi lokal di Kabupaten Sidoarjo diuji menggunakan regresi linear berganda. 


\section{Journal of Sustainability Business Research (JSBR)}

Vol-1,Issue-1,Desember (JSBR)

\section{E-ISSN: 2746-8607}

http://jurnal.unipasby.ac.id/index.php/jsbr

\section{Hipotesis}

\section{Hubungan kinerja finnansial UMKM terhadap pengembanganan ekonomi lokal}

Menginngat pentingnya peran UMKM dalam menggerakkan perekonomian Indonesia, hendaknya kendala dan keterbatasan tersebut tidak menyurutkan pelaku UMK untuk mengembangkan bisnis. Untuk melihat potensi dan kinerja UMK serta prospek dimasa mendatang perlu dilakukan analisis kinerja finansial UMKM.

Indikator Kinerja Perspektif Finansial adalah parameter-parameter keuangan yang menjadi ukuran kinerja keuangan perusahaan. Informasi tersebut diharapkan dapat memberikan sumbangsih bagi pemerintah untuk membantu pengembangan UMK baik melalui pembinaan maupun penyusunan regulasi yang melindungi dan meningkatkan perekonomian lokal (Arini, 2018).

$\mathrm{H}_{1}$ : Ada Pengaruh kinerja finansial Usaha Mikro Kecil dan Menengah (UMKM) terhadap pengembangan ekonomi lokal di Kabupaten Sidoarjo".

\section{METODE PENELITIAN}

Populasi dan Sampel

Populasi diperoleh dari laba bersih, pendapatan, biaya, dan modal UMKM yang jumlahnya 448 unit usaha di Kabupaten Sidoarjo. Sedangkan untuk mengetahui jumlah sampel maka menggunakan perhitungan :

$$
\begin{aligned}
n= & \frac{N}{1+N(e)^{2}} \\
= & \frac{448}{1+448(10 \%)^{2}} \\
= & \frac{448}{5,48} \\
= & 82
\end{aligned}
$$

Sehingga sampel yang digunakan adalah 82 unit usaha atau 18\% dari total unit UKM yang terdaftar di Dinas Koperasi dan Usaha Mikro Kabupaten Sidoarjo tahun 2018.

\section{Teknik Pengumpulan Data}

1. Penelitian kepustakaan, yang dilakukan melalui pengumpulan literatur, artikel, karangan ilmiah, yang ada kaitannya dengan permasalahan tersebut.

2. Penelitian lapangan atau observasi, dengan mengunjungi kantor Dinas Koperasi dan Usaha Mikro Kabupaten Sidoarjo.

\section{Definisi Operasional Variabel \\ Variabel Bebas}

Variabel bebasnya adalah mengukur kinerja finansial UMKM dengan indikator $N P M\left(X_{1}\right)$ dan $\operatorname{ROE}\left(X_{2}\right)$.

\section{Variabel Terikat}

Variabel terikatnya adalah pengembangan ekonomi lokal di Kabupaten Sidoarjo (Y).

\section{Teknik Analisis Data}

1. Tahap pengumpulan data.

2. Tahap editing dengan pemeriksaan jelas dan lengkapnya dalam mengumpulkan data.

3. Tahap tabulasi data dengan pencatatan dalam tabel penelitian.

4. Uji Ausmsi Klasiik

5. Uji Hipotesis

Tabel 4.1

Uji Asumsi Klasik

\begin{tabular}{ccc}
\hline $\begin{array}{c}\text { Uji Asumsi } \\
\text { Klasik }\end{array}$ & Hasil & Keterangan \\
\hline Uji Normalitas & Asymp.sig $=$ & Normal \\
\hline & 165 &
\end{tabular}


Journal of Sustainability Business Research (JSBR)

Vol-1,Issue-1,Desember (JSBR)

\section{E-ISSN: 2746-8607}

http://jurnal.unipasby.ac.id/index.php/jsbr

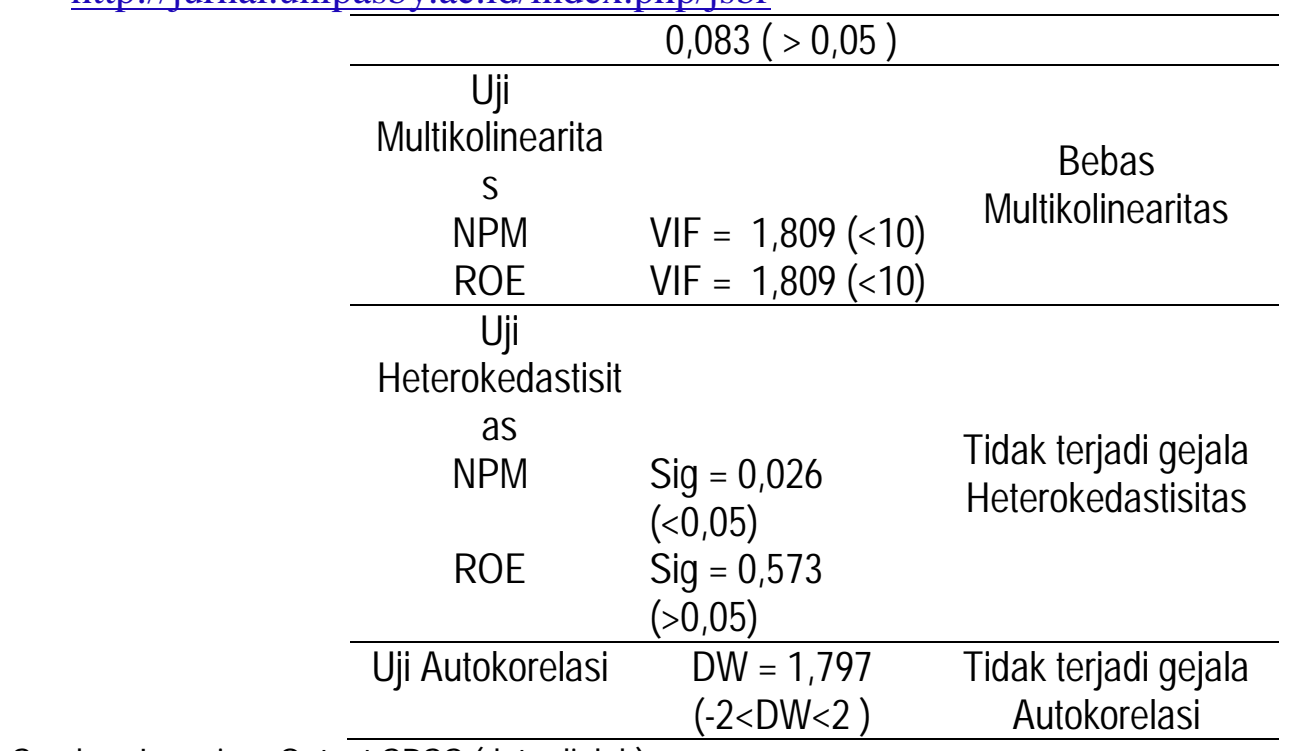

Sumber: Lampiran Output SPSS (data diolah)

\section{Regresi Linear Berganda}

Digunakan sebagai pengujian ada atau tidak adanya pengaruh antara variabel $\operatorname{NPM}\left(X_{1}\right)$ dan $\operatorname{ROE}\left(X_{2}\right)$ dengan variabel Pengembangan Ekonomi Lokal(Y). Persamaan regresi linear berganda pada penelitian ini yaitu:

$$
Y=a+\beta_{1} X_{1}+\beta_{2} X_{2}+e
$$

Dimana:

$$
\begin{aligned}
Y & =\text { Pendapatan } \\
A & =\text { Konstanta } \\
\beta_{1} \beta_{2} & =\text { Koefisien Regresi } \\
X_{1} & =\text { NPM } \\
X_{2} & =\text { ROE } \\
E & =\text { Error Term }
\end{aligned}
$$

Tabel 4.2

Analisis Regresi Linear Berganda

\begin{tabular}{ll}
\hline Variabel & Hasil \\
\hline Koefisien Korelasi (R) & 0,662 \\
KoefisienDeterminasi (R) & 0,439 \\
Constant & 144979,638 \\
Net Profit Margin (NPM) $\left(\mathrm{X}_{1}\right)$ & $-97685,653$ \\
Return On Equity (ROE) $\left(\mathrm{X}_{2}\right)$ & $-139672,571$ \\
Error Term & 17830,692 \\
Sumber: data diolah &
\end{tabular}

Dari data diolah di atas sehingga diperoleh persamaan:

$Y=144979,638-97685,653 X_{1}-139672,571 X_{2}+346,88843$

Dari persamaan regresi tersebut dapat dijelaskan sebagai berikut:

a. Nilai koefisien konstanta $=144979,638$

Jika nilai dari keseluruhan variabel yaitu Net Profit Margin (NPM) dan Return On Equity (ROE) sama dengan nol, maka Pendapatan Lokal sebesar 144979,638.

b. Nilai koefisien $X_{1}=-97685,653$

Jika Net Profit Margin (NPM) mengalami kenaikan satu poin (\%) maka akan menyebabkan penurunan Pendapatan Lokal sebesar $-97685,653$ poin. Arti dari koefisien negatif adalah variabel bebas mempunyai hubungan yang 


\section{Journal of Sustainability Business Research (JSBR)}

\section{Vol-1,Issue-1,Desember (JSBR)}

\section{E-ISSN: 2746-8607}

http://jurnal.unipasby.ac.id/index.php/jsbr

terbalik terhadap variabel terikat.

C. Nilai koefisien $\mathrm{X}_{2}=-139672,571$

Apabila Return On Equity (ROE) meningkat satu poin (\%), maka Pendapatan Lokal juga akan meningkat sebesar -

139672,571 poin. Arti dari koefisien negatif adalah variabel bebas mempunyai hubungan yang terbalik terhadap variabel terikat.Koefisien Korelasi (R)

Sesuai dengan hasil hitung dari output SPSS, bahwa nilai koefisien korelasi (R) sebesar 0,662 $(R>0,5)$ yang menunjukkan adanya hubungan antara kinerja finansial Usaha Mikro Kecil dan Menengah (UMKM) dengan Pendapatan lokal adalah sangat kuat.

\section{Pembahasan}

\section{Hipotesis Simultan (Uji F)}

Hasil pengujian hipotesis diperoleh nilai $F_{\text {hitung }}$ sebesar 30,868 serta nilai sig, yaitu dengan cara nilai signiifkansi (Sig) 0,000 atau $<0,05$ maka hipotesis diterima artinya ada pengaruh kinerja fiinansial UMKM terhadap pengembangan ekonomi lokal.

Tabel 4.3

Hasil Pengujian Hipotesis Simultan Uji-F

\begin{tabular}{cccc}
\hline $\boldsymbol{F}_{\text {hitung }}$ & Sig & Kriteria & Keterangan \\
\hline 30,868 & 0,000 & $<0,05$ & Signifikan \\
\hline \multicolumn{4}{c}{ Sumber:data diolah }
\end{tabular}

Pengembangn UMKM melalui penilaian dan pengukuran inndikator kinerja finansial dilakukan untuk memberikan gambaran serta peran unit usahanya. Informasi tersebut diberikan kepada pemerintah dalam hal ini dinas koperasi dan ukm Kabupaten Sidoarjo untuk membantu pengembangan unit usaha. Dengan demikian peran kinerja UMKM dalam kegiatan ekonomi lokal sangat kuat.

\section{KESIMPULAN}

Berdasarkan hasil analisis data, penilaian kinerja Finansial UMKM sangat penting sebagai indikator kemajuan UMKM terhadap Pengembangan Ekonomi Lokal di Kabupaten Sidoarjo.

\section{IMPLIKASI}

Implementasi peran pemerintah Kabupaten Sidoarjo yang efektif akan memberikan implikasi yang sangat penting pada berbagai aspek baik aspek manajerial maupun aspek finansial UMKM. Aspek penyelenggaraan pengembangan beserta berbagai program pelatihan UMKM diharapkan dapat menciptakan kondisi perekonomian daerah yang efektif.

\section{KETERBATASAN}

Keterbatasan pada saat pengambilan data dikarenakan tidak seluruh pelaku UMKM mendaftarkan usahanya kepada Dinas Koperasi dan UMKM Kabupaten Sidoarjo. Serta minimnya informasi yang kurang lengkap mengenai data pelaporan keuangan pemeritah Kabupaten Sidoarjo.

\section{DAFTAR RUJUKAN}

Adji, M. M. 2011. Konsep Pengembangan Ekonomi Lokal Perkotaan, Makalah pada Sosialisasi Pengembangan Ekonomi Lokal Perkotaan se-Provinsi Riau, Pekan Baru, 18 Juli 2011, Badan Perencanaan Pembangunan NasionalRI.http://www.usdrpindonesia.org/files/downloadContent[diakses 5 September 2011]

Gani Irawan dan Siti Amalia. 2018. Alat Analisis Data Aplikasi Statistik Untuk Penelitian Bidang Ekonomi dan Sosial. Yogyakarta: ANDI

Lia, Della Ayu Zonna, Rustam Hidayat dan Zahro Z.A. 2015. Penilaian Kinerja Keuangan Pada Usaha Kecil dan Menengah (UKM) Berdasarkan Analisis Rasio Keuangan (Studi Pada IRT Ramayana Agro Mandiri Kota Batu Tahun 2011-2014). Jurnal Administrasi Bisnis Vol. 25 No. 01.

Pemerintah Indonesia. 2008. Undang-Undang Republik Indonesia Nomor 20 Tahun 2008 Tentang Usaha Mikro, Kecil, dan Menengah. Lembaran RI Tahun 2008 No. 93. Jakarta: Sekretariat Negara. 


\section{Journal of Sustainability Business Research (JSBR)}

Vol-1,Issue-1,Desember (JSBR)

E-ISSN: 2746-8607

http://jurnal.unipasby.ac.id/index.php/jsbr

Saragih, Jef Rudhianto. 2018. Perencanaan Wilayah dan Pengembangan Ekonomi Lokal Berbasis Pertanian. Yogyakarta: Pustaka Pelajar

Soemohadiwidjojo, Arini T. 2018. SOP dan KPI untuk UMKM \& Startup. Jakarta: Raih Asa Sukses (Penebar Swadaya Grup)

Sugiyono. 2017. Metode Penelitian Kuantitatif, Kualitatif, dan R\&D. Bandung: Alfabeta

Sujarweni, V. Wiratna. 2018. Metodologi Penelitian Bisnis dan Ekonomi Pendekatan Kuantitatif. Yogyakarta: Pustaka Baru Press.

Tanjung, M. Azrul. 2017. Koperasi dan UMKM sebagai Fondasi Perekonomian Indonesia. Jakarta: Erlangga

www.sidoarjokab.bps.go.id Badan Pusat Statistik Kabupaten Sidoarjo 